\title{
A cytogenetic study of Baryscapus silvestrii Viggiani et Bernardo, 2007 (Hymenoptera: Eulophidae) using base-specific fluorochrome staining
}

\section{Цитогенетическое исследование Baryscapus silvestrii Viggiani et Bernardo, 2007 (Hуmenoptera: Eulophidae) с помощью окраски базоспецифическими фкуорохромами}

\author{
V.E. Gokhman ${ }^{1}$, F. Nugnes ${ }^{2}$, U. Bernardo \\ B.Е. Гохман ${ }^{1}, \Phi$. Нуньес $^{2}$, У. Бернардо
}

\footnotetext{
Botanical Garden, Moscow State University, Moscow, Russia. E-mail: vegokhman@hotmail.com

${ }^{2}$ Institute for Sustainable Plant Protection, Italian National Research Council, Portici (Napoli), Italy. E-mail: francesconugnes82@gmail.com ${ }^{3}$ Institute for Sustainable Plant Protection, Italian National Research Council, Portici (Napoli), Italy. E-mail: umberto.bernardo@ipsp.cnr.it Ботанический сад Московского государственного университета, Москва, Россия. E-mail: vegokhman@hotmail.com
}

KEY WORDS. Parasitoids, chromosomes, karyotypes, NORs, CMA, DAPI.

КЛЮЧЕВЫЕ СЛОВА. Наездники, хромосомы, кариотипы, NOR, CMA, DAPI.

ABSTRACT. Chromosomes of Baryscapus silvestrii Viggiani et Bernardo, 2007 (Eulophidae) with $\mathrm{n}=6$ and $2 \mathrm{n}=12$ were studied using base-specific fluorochrome staining. Chromomycin $\mathrm{A}_{3}$ / 4', 6-diamidino-2phenylindole $\left(\mathrm{CMA}_{3} / \mathrm{DAPI}\right)$ staining revealed a single paired $\mathrm{CMA}_{3}$-positive band within the diploid karyotype of $B$. silvestrii. This CG-rich segment apparently corresponds to the nucleolus organizing region (NOR). Certain features of karyotype evolution of parasitoids of the family Eulophidae are discussed.

РЕЗЮМЕ. Хромосомы Baryscapus silvestrii Viggiani et Bernardo, 2007 (Eulophidae) с $n=6$ и 2n $=12$ изучены с помощью окраски базоспецифическими флуорохромами. Окраска хромомицином А / 4', 6диамидино-2-фенилиндолом (CMA $/$ DAPI) выявила единственный парный $\mathrm{CMA}_{3}$-положительный сегмент в диплоидном кариотипе $B$. silvestrii. Этот сегмент, обогащённый ГЦ-парами оснований, очевидно, соответствует ядрышкообразующему району (NOR). Обсуждаются некоторые особенности эволюции кариотипа наездников семейства Eulophidae.

\section{Introduction}

Parasitoid Hymenoptera are one of the most speciesrich, taxonomically complicated and economically important groups of insects [Godfray, 1994; Quicke, 1997]. In particular, the superfamily Chalcidoidea, with its exceptionally high morphological and ecological diversity, contains about 23 thousand known species [Huber, 2017], but karyotypes of less than 200 members of this group are studied up to now [Gokhman, 2013]. Moreover, chromosome sets of these insects are rarely investigated using base-specific fluorochromes, which often reveal previously unknown karyotypic features [Bolsheva et al., 2012; Gokhman et al., 2017b]. To promote further understanding of these patterns, we have recently studied the chromosome set of a particular chalcid wasp, Baryscapus silvestrii Viggiani et Bernardo, 2007 (Eulophidae) using base-specific fluorochrome staining. Baryscapus silvestrii is a gregarious parasitoid of the olive fly Bactrocera oleae (Rossi, 1790) (Diptera: Tephritidae) that was described more than a decade ago from Southern Italy [Viggiani et al., 2007].

Material and methods

\section{Origin of parasitoids}

The strain of $B$. silvestrii used in the present study is kept as a lab stock at the Institute for Sustainable Plant Protection, Italian National Research Council, Portici (Napoli), Italy. It is reared on Ceratitis capitata (Wiedemann, 1824) (Diptera: Tephritidae) in a climate-controlled chamber at $25 \pm 1{ }^{\circ} \mathrm{C}, 60 \pm 10 \%$ relative humidity, and 16:8 hours photoperiod (L:D). This lab stock originates from insects reared from puparia of $B$. oleae collected in 2014 on infested olive fruits in Portici.

How to cite this article: Gokhman V.E., Nugnes F., Bernardo U. 2019. A cytogenetic study of Baryscapus silvestrii Viggiani et Bernardo, 2007 (Hymenoptera: Eulophidae) using base-specific fluorochrome staining // Russian Entomol. J. Vol.28. No.2. P.180 -182. doi: 10.15298/rusentj.28.2.10 
Recently, these parasitoids have been characterized through a molecular approach (see [Nugnes et al., 2016]).

\section{Preparation of chromosomes}

Chromosomal preparations were obtained from cerebral ganglia of parasitoid prepupae generally following the protocol developed by Imai et al. [1988] with certain modifications [Gokhman et al., 2017a, b]. Ganglia were extracted from insects dissected in $0.5 \%$ hypotonic sodium citrate solution containing $0.005 \%$ colchicine. The extracted ganglia were then transferred to a fresh portion of hypotonic solution and incubated for 30 min at room temperature. The material was transferred onto a pre-cleaned microscope slide using a Pasteur pipette and then gently flushed with Fixative I (glacial acetic acid: absolute ethanol: distilled water $3: 3: 4$ ). The tissues were disrupted using dissecting needles in an additional drop of Fixative I. Another drop of Fixative II (glacial acetic acid: absolute ethanol 1:1) was applied to the center of the area, and the more aqueous phase was blotted off the edges of the slide. The slides were then dried for approximately half an hour and stored at room temperature for a few months.

\section{Chromosome staining}

To confirm the results of routine chromosome staining in $B$. silvestrii, several preparations were stained with freshly prepared 3\% Giemsa solution in $0.05 \mathrm{M}$ Sorensen's phosphate buffer $\left(\mathrm{Na}_{2} \mathrm{HPO}_{4}+\mathrm{KH}_{2} \mathrm{PO}_{4}, \mathrm{pH}\right.$ 6.8 ) for a few hours. Fluorochrome staining with chromomycin $\mathrm{A}_{3}$ and 4', 6-diamidino-2-phenylindole (CMA / DAPI) was performed according to Schweizer [1976] with certain modifications by Bolsheva et al. [2012]. The slide was flooded with $\mathrm{CMA}_{3}$ staining solution $(0.5 \mathrm{mg} / \mathrm{ml}$ in Mcllvaine's buffer containing $5 \mathrm{mM}$ $\mathrm{MgCl}_{2}$ ), covered with a coverslip, and incubated in the dark for about ten days. The coverslip was then removed, and the slide was briefly rinsed with distilled water and air-dried. The slide was then flooded with DAPI solution ( $2 \mu \mathrm{g} / \mathrm{ml}$ in McIlvaine's buffer), covered with a coverslip, and stained in the dark for $30 \mathrm{~min}$. The coverslip was then removed, and the slide was briefly rinsed with distilled water before being air-dried. The preparation was then mounted in a mixture of glycerin and McIlvaine's buffer $(1: 1)$ containing $2.5 \mathrm{mM} \mathrm{MgCl}$, and sealed with rubber cement. The slide was stored in the dark prior to examination for a minimum of three days.

\section{Image acquisition and analysis}

Metaphase plates were analyzed under Zeiss Axioskop 40 FL epifluorescence microscope (Carl Zeiss, Oberkochen, Germany). Images of chromosomes were taken with Zeiss AxioCam MRc digital camera using Zeiss AxioVision software version 3.1. To prepare illustrations, the resulting images were arranged and enhanced with Adobe Photoshop 8.0. KaryoType version 2.0 software was also used for taking chromosome measurements. The chromosomes were classified following guidelines provided by Levan et al. [1964].

\section{Results and discussion}

Four large metacentric chromosomes of similar size, a smaller metacentric and the smallest acrocentric chromosome were found in the haploid karyotype of this species with $\mathrm{n}=6$ and $2 \mathrm{n}=12$ (Figs $1-2$ ). We also found that total length of the haploid chromosome set of $B$. silvestrii is substantially higher than that of the diploid one divided by two $(29.7 \pm 5.1$ vs. $20.1 \pm 2.8 \mu \mathrm{m}$, mean $\pm \mathrm{SD}$, data from ten haploid and four diploid plates of the same male individual). Fluorochrome staining of the diploid karyotype visualized a single pericentromeric $\mathrm{CMA}_{3}$-positive band on both homologous medium-sized metacentric chromosomes, probably the second largest ones (Fig. 3). DAPI staining did not reveal any banding pattern on chromosomes of B. silvestrii (Fig. 4).

The chromosome set of $B$. silvestrii was first studied by Gebiola \& Bernardo [2008] who found $n=6$ and $2 n$ $=12$ with the above-mentioned karyotype structure in this species, and we therefore confirm these results. As far as the very phenomenon of generally higher absolute chromosome lengths of haploid vs. diploid karyotypes of the Hymenoptera is concerned, the most plausible explanation for that was apparently suggested by Gokhman et al. [2017a]. Specifically, we consider this situation as a consequence of the lower condensation of

\section{1. illition}

Figs $1-2$. Karyograms of B. silvestrii: 1 - haploid $(\mathrm{n}=6) ; 2$ diploid $(2 \mathrm{n}=12)$. Scale bar: $10 \mu \mathrm{m}$.

Рис. 1-2. Кариограммы B. silvestrii: 1 - гаплоидная $(\mathrm{n}=6)$; 2 - диплоидная $(2 \mathrm{n}=12)$. Масштаб: $10 \mu \mathrm{m}$.

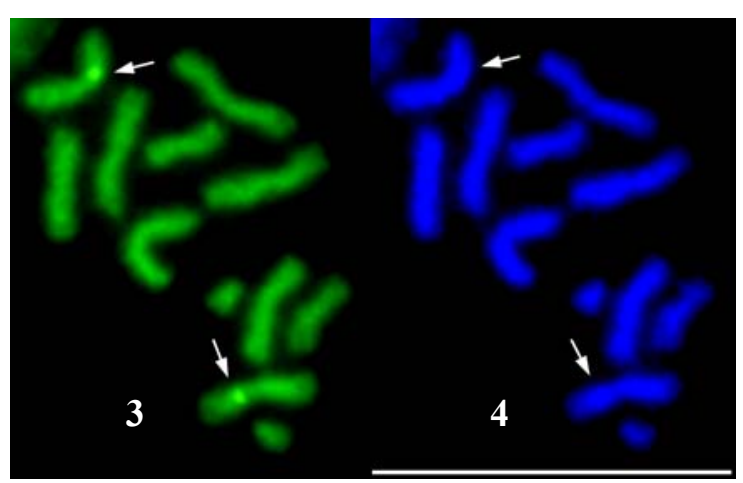

Figs 3-4. $\mathrm{CMA}_{3} / \mathrm{DAPI}-$ stained diploid metaphase plate of $B$. silvestrii: 3 - $\mathrm{CMA}_{3}$ staining; 4 - DAPI staining. Arrows indicate position of $\mathrm{CMA}_{3}$-positive bands (NORs). Scale bar: $10 \mu \mathrm{m}$.

Рис. 3-4. Диплоидная метафазная пластинка B. silvestrii, окраска $\mathrm{CMA}_{3} / \mathrm{DAPI}: 3$ - окрашивание $\mathrm{CMA}_{3} ; 4$ - окрашивание DAPI. Стрелки указывают положение $\mathrm{CMA}_{3}$-положительных сегментов (NOR). Масштаб: $10 \mu \mathrm{m}$. 
chromosomes of the haploid set, which, in turn, is necessary to ensure similar levels of transcription in both haploid and diploid cells.

The karyotype structure of $B$. silvestrii (i.e., five larger metacentrics and a smaller acrocentric chromosome) is also similar to that of many other members of the subfamily Tetrastichinae (see e.g. Gokhman, 2009). Moreover, this pattern is apparently the commonest in the family Eulophidae in general [Gokhman, 2009; Gokhman, Gumovsky, 2009; Bolsheva et al., 2012; Gokhman et al., 2014] which is, in turn, one of the best karyotypically studied chalcid families, with chromosome sets of more than 60 species being currently known (see e.g. Gokhman, 2009; Gebiola et al., 2012).

Fluorochrome staining revealed the only paired $\mathrm{CMA}_{3}$-positive band on the chromosomes of $B$. silvestrii. As in many other chalcid wasps studied in this respect, this segment apparently corresponds to the nucleolus organizing region (NOR). Furthermore, a similar NOR position is characteristic of some other members of the subfamily Tetrastichinae (Eulophidae). Specifically, Gokhman et al. [2017b] also found a single interstitial NOR that is relatively close to the centromere of a large metacentric chromosome in Palmistichus elaeisis Delvare et LaSalle, 1993 from Brazil which has $\mathrm{n}=6$ as well. However, base-specific fluorochrome staining in another Brazilian member of Tetrastichinae, Trichospilus diatraeae Cherian et Margabandhu, 1942 with $n=7$, visualized telomeric $\mathrm{CMA}_{3}$ positive and DAPI-negative bands on every chromosome [Gokhman et al., 2017b], although the precise number and localization of NORs in this species remains unknown. In addition, a single NOR was also detected by $\mathrm{CMA}_{3} / \mathrm{DAPI}$ staining and FISH with a $45 \mathrm{~S}$ rDNA probe in both Entedon cionobius Thomson, 1878 and E. cioni Thomson, 1878 from the subfamily Entedoninae (Eulophidae); nevertheless, this NOR is situated close to the centromere on the longer arm of the only acrocentric chromosome [Bolsheva et al., 2012].

Acknowledgement. The present study was partly supported by a research grant no. 18-04-00611 from the Russian Foundation for Basic Research to VEG.

\section{References}

Bolsheva N.L., Gokhman V.E., Muravenko O.V., Gumovsky A.V., Zelenin A.V. 2012. Comparative cytogenetic study on two species of the genus Entedon Dalman, 1820 (Hymenoptera: Eulophidae) using DNA-binding fluorochromes and molecular and immunofluorescent markers // Comparative Cytogenetics. Vol.6. No.1. P.79-92. doi: 10.3897/compcytogen.v6i1.2349.
Gebiola M., Bernardo U. 2008. Karyotype of Baryscapus silvestrii Viggiani et Bernardo (Hymenoptera: Eulophidae) // Bollettino del Laboratorio di Entomologia Agraria "Filippo Silvestri". Vol.62. P.39-43.

Gebiola M., Giorgini M., Navone P., Bernardo U. 2012. A karyological study of the genus Pnigalio Schrank (Hymenoptera: Eulophidae): Assessing the taxonomic utility of chromosomes at the species level // Bulletin of Entomological Research. Vol.102. P.43-50. doi: 10.1017/s0007485311000356.

Godfray H.C.J. 1994. Parasitoids: behavioral and evolutionary ecology. Princeton: Princeton University Press. XI + 475 pp.

Gokhman V.E. 2009. Karyotypes of parasitic Hymenoptera. Dordrecht: Springer. XIII + 183 pp. doi: 10.1007/978-1-4020-9807-9.

Gokhman V.E. 2013. Parallel pathways of karyotype evolution in the superfamily Chalcidoidea (Hymenoptera) // Russian Entomological Journal. Vol.22. No.3. P.177-179.

Gokhman V.E., Gumovsky A.V. 2009. Main trends of karyotype evolution in the superfamily Chalcidoidea (Hymenoptera) // Comparative Cytogenetics. Vol.3. No.1. P.63-69. doi: 10.3897/ compcytogen.v3i1.1.

Gokhman V.E., Kuhn K.L., Woolley J.B., Hopper K.R. 2017a. Variation in genome size and karyotype among closely related aphid parasitoids (Hymenoptera, Aphelinidae) // Comparative Cytogenetics. Vol.11. No.1. P.97-117. doi: 10.3897/ ccompcytogen.v11i1.10872.

Gokhman V.E., Pereira F.F., Costa M.A. 2017b. A cytogenetic study of three parasitic wasp species (Hymenoptera, Chalcidoidea, Eulophidae, Trichogrammatidae) from Brazil using chromosome morphometrics and base-specific fluorochrome staining // Comparative Cytogenetics. Vol.11. No.1. P.179-188. doi: 10.3897/ compcytogen.v11i1.11706.

Gokhman V.E., Yefremova Z.A., Yegorenkova E.N. 2014. Karyotypes of parasitic wasps of the family Eulophidae (Hymenoptera) attacking leaf-mining Lepidoptera (Gracillariidae, Gelechiidae) // Comparative Cytogenetics. Vol.8. No.1. P.31-41. doi: 10.3897/ compcytogen.v8i1.6357.

Huber J.T. 2017. Biodiversity of Hymenoptera // Foottit R.G., Adler P.H. (eds). Insect biodiversity: science and society. 2nd Edition. Oxford: Wiley Blackwell. P.419-461.

Imai H.T., Taylor R.W., Crosland M.W.J., Crozier R.H. 1988. Modes of spontaneous chromosomal mutation and karyotype evolution in ants with reference to the minimum interaction hypothesis // Japanese Journal of Genetics. Vol.63. P.159-185. doi: $10.1266 /$ jjg.63.159.

Levan A., Fredga K., Sandberg A.A. 1964. Nomenclature for centromeric position on chromosomes // Hereditas. Vol.52. P. 201220. doi: 10.1111/j.1601-5223.1964.tb01953.x.

Nugnes F., Gebiola M., Gualtieri L., Russo E., Sasso R., Bernardo U. 2016. When exotic biocontrol agents travel without passport: first record of Quadrastichus mendeli, parasitoid of the bluegum chalcid Leptocybe invasa, in Italy // Bulletin of Insectology. Vol. 69. No.1. P.85-91.

Quicke D.L.J. 1997. Parasitic wasps. London: Chapman \& Hall. XVII $+470 \mathrm{pp}$.

Schweizer D. 1976. Reverse fluorescent chromosome banding with chromomycin and DAPI // Chromosoma. Vol.58. P.307-324. doi: $10.1007 / \mathrm{bf00292840.}$

Viggiani G., Bernardo U., Sasso R. 2007. Description of Baryscapus silvestrii (Hymenoptera: Eulophidae), a new gregarious parasitoid of the olive fly Bactrocera oleae (Gmelin) (Diptera: Tephritidae) in southern Italy // Bollettino del Laboratorio di Entomologia Agraria "Filippo Silvestri". Vol.61. P.63-70. 